\section{German Higher Education at the Millennium}

\section{Barbara M. Kehm}

Barbara M. Kehm is on the staff of the Institute for Higher Education Research at the Martin Luther University, Wittenberg, Germany. Address: Collegienstr. 62 b, D-06886 Lutherstadt Wittenberg, Germany. Fax: +49-3491-466255 E-mail: <kehm@hof.uni.halle.de>.

$\mathrm{D}$ ebates about weaknesses in West German higher education and the need for reform were almost completely set aside upon German unification in 1990. For a few years, all attention was absorbed by the transformation, restructuring, and renewal of East German higher education, after the West German model. This included efforts to update technological standards, reduce overstaffing, evaluate remaining academic staff for performance and political bias, reverse the separation between teaching and research, resolve curricular and disciplinary discrepancies, and increase enrollments. The final task was to adapt the existing East German system to that in the West by closing down many of the academies and establishing universities of applied sciences (Fachbochschulen). Many experts favored salvaging at least some of the positive elements in East German higher education. However, no one challenged the priority placed on a rapid transplantation of the West German system of higher education into the East.

In the second half of the 1990s, issues pending in the West German system were back on the agenda. Very much in the foreground of current reform debates are duration of studies, introduction of tuition fees, promoting competition and differentiation, new forms of management, lumpsum budgeting, performance-based funding, as well as teaching evaluations. The assessment of East German higher education and research has led to a critical scrutiny of West German higher education. In addition, the federal government managed to enact a new higher education framework law. The law was controversial, less because it did away with the principle of homogeneity in German higher education than because it omitted an explicit ban on tuition fees. Overall, a spirit of renewal and innovation prevails at all levels, and hopes are high for modernizing German higher education and making it more competitive and effective.

\section{Governmental Steering and Deregulation}

In recent years, criticisms of institutional inertia, especially in West Germany, have prompted a search for new and more flexible mechanisms to deal with problems and adapt to change. Federal and state governments are trying to reduce "overregulation" and introduce competitive elements into a rather homogeneous system. Deregulation and differentiation are key concepts in this context.
Higher education institutions themselves have welcomed and supported profile building and institutional differentiation, while rejecting the introduction of institutional rankings. The ambivalence among the actors in higher education might be based on these factors: (a) market concepts and differentiation are unfamiliar to German higher education; (b) consensus has not yet been reached concerning the indicators on which to base differentiation; (c) people are reluctant to renounce the principles of homogeneity and basic equality among institutions of one type and concerned about the fate of the potential losers in a competitive and differentiated system; and (d) institutional profile building is still rather tentative because self-marketing and niche marketing are new concepts.

Very much in the foreground of current
reform debates are duration of studies,
introduction of tuition fees, promoting
competition and differentiation, new
forms of management, lump-sum bud-
geting, performance-based funding, as
well as teaching evaluations.

\section{Institutional Autonomy}

Debates about a "legitimation crisis" in German higher education are centered around three themes. First, it is widely felt that higher education institutions should become more efficient and professors more accountable for their teaching and research. Second, belief in the virtue of a more or less homogeneous system of higher education has eroded. The development of specific institutional profiles, however, will lessen the need for governmental planning and shift more power to the institutions themselves. Third, a reduction in government steering and control would require university presidents or rectors, as well as deans, to assume a more managerial and professional role.

However, a close look at the various models and pilot projects shows that increased institutional autonomy is not granted unconditionally. State regulation will tend to move into areas not previously subjected to control—resulting, for example, in new forms of institutional accountability. State control is shifting from a focus on input and process to one stressing output. At the same time, input and process will come under the supervision of a strengthened and professionalized institutional management, including the experimental introduction of boards of trustees. These changes will certainly affect the tradition of collegiality in academic self-governance and the participatory model of the "group university" established in the early 1970s. How- 
ever, institutions will be better able to exercise strategic planning, generate institutional income, and implement more flexible organizational and administrative policies. Thus, not only has the relationship between higher education institutions and the state changed, but there is also a general opening up of the system to external and international modes of operation.

\section{Securing and Expanding Resources}

Faced with the immense cost of German unification and the general stringency of the public purse, higher education has had to absorb considerable funding cuts during the last decade. Institutions have begun to search for ways to diversify their funding base in order to improve resources and income. A number of pilot projects are working with lump-sum budgets, although most institutions still operate with line-item budgets. Institutions experimenting with lump-sum budgets, have welcomed the potential for strategic planning and flexibility in the internal allocation of funds. On the downside, conflicts previously solved in direct negotiation with the responsible state ministry have now shifted to the institutions themselves. Moreover, some state governments are seeking to introduce elements of performance-related funding.

However, the question of tuition fees is probably the most controversial one currently being debated in German higher education. Many actors openly or secretly advocate tuition fees and most institutions would welcome the improvement in their financial resources. But they have so far resisted the introduction of fees for fear that the state governments might indirectly appropriate these additional funds by cutting back on the provision of basic resources. The new higher education framework law almost failed to be passed over this issue. In the long term, tuition fees are likely to be introduced, possibly at first only in some German states.

\section{State control is shifting from a focus on input and process to one stressing output.}

\section{Evaluation and Quality of Teaching}

In principle, the unity of teaching and research continues to be an important aspect of the idea of the German university. However, changing economic and social expectations as regards the qualifications of graduates have contributed to growing demands for a higher degree of practical orientation in the traditional university curriculum. At the same time, universities of the applied sciences are showing signs of "academic drift." Professors and other academic staff are under attack about the quality of teaching. In turn, academic staff complain about an overload in administrative and teaching duties that force them to neglect research. Dissatisfaction with the quality of teaching, high dropout rates, and a long duration of studies, coupled with stagnating resources, have led to many initiatives to assess and improve the situation.

After the East German higher education system had been subjected to comprehensive screening and evaluation, West German resistance against evaluation and assessment was no longer tenable. However, institutions have tended to develop their own approaches and procedures. These bottom-up initiatives also serve to prevent the imposition of evaluation procedures by the state and possibly the involvement of external stakeholders. Self-initiated internal evaluations tend to be less threatening and more predictable. The federal government and the states are also discussing general guidelines to ensure teaching quality. As part of this effort, a special program for higher education development supports projects coordinated by the German Rectors' Conference. Currently, workshops are organized to exchange information about the various evaluation procedures and models developed by institutions themselves. The aim is to develop a more general model for the evaluation and quality assurance of teaching in higher education.

\section{Internationalization}

In recent years, great concern has been voiced by the federal government and other political actors that studying in Germany had become increasingly unattractive to foreigners. Higher education institutions have been faulted for not paying sufficient attention to the relevance and attractiveness of their curricula to foreign students. Other complaints focus on the lengthy duration of studies; the incompatibility, internationally, of German degrees; the lack of transparency in the organization of academic programs; and the failure to provide sufficient advisement and counseling to foreign students. This critique overlooks not only the many cooperative arrangements but also the successful participation of German higher education institutions in European programs for the promotion of international cooperation and mobility. Attention has focused on the decrease in foreign applicants from the Asian and Pacific regions as well as some of the more prosperous Latin American countries. It was feared that if they studied elsewhere, the future leaders and managers of these target countries would be less inclined to provide opportunities for German exports and investments, with competitive disadvantages for the German economy.

A number of pilot projects have therefore been funded by the states and the federal government, offering bachelor's and master's degrees, and courses of study specifically catering to the qualification needs of foreign students. The projects also often include course offerings in English. The number of institutions wanting to participate in the pilot projects far surpasses the number of available programs. It remains unclear, however, whether a broader introduction of interna- 
tionally recognized degrees will change the binary system of universities and universities of applied sciences in Germany. Also uncertain is whether meeting the pressure for innovation will result in a less costly, intensive, and short-cycle higher education for the majority of students and bachelor's and master's degrees for the elite.

\section{Higher Education after German Unification}

Examining German higher education reform in the context of German unification leaves out the fact that in German society as a whole, as well as in Europe and elsewhere, requirements for higher education and research are in flux. Still, the transfer of the West German higher education system into the new East German states has had repercussions on the German system as a whole. Moreover, higher education institutions in the new East German states are beginning to initiate some innovations that may in turn lead to further reforms of the system as a whole: (a) Eastern Germany is acknowledged to have a higher quality of teaching and supervision and a shorter duration of studies; (b) science and research have acquired a special role for regional transfer of knowledge and skills since the substantial economic breakdown after 1989; (c) due to the comprehensive renewal after unification, higher education structures in the East are less rigid and more open to innovation and experimentation, in terms of academic programs and curricular content as well as interdisciplinary approaches to research and teaching. Thus, historically determined disadvantages in East German higher education might well turn into conceptual advantages in the long run.

\section{Future Perspectives}

Three problem areas can be identified that reinforce the perception that the German higher education system is in crisis: (a) a questioning of the idea of the German university, which is based on the Humboldtian reforms in the early 19th century; (b) structural problems, linked to a perceived lack in quality and transparency in higher education; (c) administrative problems, centering on doubts about the efficiency of institutional management, administration, and budgeting. However, one prerequisite for addressing these issues in both East and West German higher education is appropriate funding or at least the provision of financial incentives. Without adequate funding, higher education institutions will continue to react to public and political pressure by referring to their lack of adequate funding. This impasse has been characterized as Germany's "reform congestion.”

Nevertheless, higher education reform in Germany is beginning to develop a dynamic widely viewed as positive. The multitude of pilot projects and innovative approaches to higher education organization, administration, teaching, studying, and curricular development show action is beginning to replace inertia and also that the rather homogeneous structure itself is beginning to dissolve.

\section{Five Suggestions for the Newly Elected Rector of the University of Oslo}

\section{Arild Tjeldvoll}

Arild Tieldvoll is professor of education at the University of Oslo. Address: Helga Engs Hus, University of Oslo, Blindern, Oslo, Norway.

$\mathrm{O}_{\mathrm{i}}^{\mathrm{n}}$ October 12, 1998 the University of Oslo elected its new rector (president). For several months before the election an unusually lively debate about university policies had been carried in the leading newspapers. My review in the Aftenposten (August 6, 1998) of Burton Clark's recent book, Entrepreneurial Universities, set off an almost heated exchange about the most relevant leadership qualities in a new rector. My article also related Clark's "five organizational pathways of transformation" to the current economic situation of the University of Oslo, which several professors had labeled a crisis. Five senior professors ran for the office of the rector in the University of Oslo's first election campaign. This event was interpreted by some as a sign that international trends in higher education had reached Norwegian shores.

On election night, the university newspaper, Uniforum, asked five people, myself included, to give the new rector five "good recommendations." These were my suggestions:

Recommendation 1: Analyze the relationship between the University and its owner, the Norwegian state. Recent debates have highlighted deep concerns among professors about how the state is fulfilling its ownership responsibilities toward the University. For a number of years the state has reduced funding while granting more autonomy. Also, the 1995 higher education act puts the universities and all other higher education institutions on the same legal and financial footing.

The state has decided that all institutions shall be parts of the Norway Network, and has opened the door to specialization in research and education and, indirectly, competition in the higher education sector. Hence, the state as the University of Oslo's owner has changed its role rather dramatically. The new rector urgently needs to determine the University's real autonomy in relation to the state and the overall situation. Also, the university needs to learn what the state will contribute financially in the coming years, and with which strings.

Recommendation 2: Identify and utilize the University's own buman resources for university policy analysis. A few years ago, when the University of Oslo decided to rationalize its huge administration (which is, to a considerable de- 